\title{
Article \\ Diffusible Compounds Produced by Hanseniaspora osmophila and Gluconobacter cerinus Help to Control the Causal Agents of Gray Rot and Summer Bunch Rot of Table Grapes
}

\author{
Matías Olivera ${ }^{1}$, Ninoska Delgado ${ }^{1}$, Fabiola Cádiz ${ }^{1}$, Natalia Riquelme ${ }^{1}$, Iván Montenegro ${ }^{2, *} \mathbb{1}$,

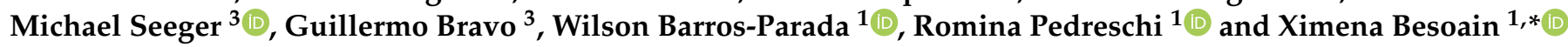 \\ 1 Escuela de Agronomía, Facultad de Ciencias Agronómicas y de los Alimentos, Pontificia Universidad \\ Católica de Valparaíso, Quillota 2260000, Chile; matias.olivera.a@mail.pucv.cl (M.O.); \\ ninoska.delgado.p@mail.pucv.cl (N.D.); fabiola.cadiz@pucv.cl (F.C.); natalia.riquelme.a@mail.pucv.cl (N.R.); \\ wilson.barros@pucv.cl (W.B.-P.); romina.pedreschi@pucv.cl (R.P.) \\ 2 Escuela de Obstetricia y Puericultura, Facultad de Medicina, Universidad de Valparaíso, \\ Viña del Mar 2520000, Chile \\ 3 Molecular Microbiology and Environmental Biotechnology Laboratory, Department of Chemistry \& Center of \\ Biotechnology Daniel Alkalay Lowitt, Federico Santa María Technical University, Valparaíso 2340000, Chile; \\ michael.seeger@usm.cl (M.S.); bravoc.guillermo@gmail.com (G.B.) \\ updates \\ Citation: Olivera, M.; Delgado, N.; \\ * Correspondence: ivan.montenegro@uv.cl (I.M.); ximena.besoain@pucv.cl (X.B.); Tel.: +56-32-237-2930 (X.B.)
} Cádiz, F.; Riquelme, N.; Montenegro,

I.; Seeger, M.; Bravo, G.;

Barros-Parada, W.; Pedreschi, R.; Besoain, X. Diffusible Compounds Produced by Hanseniaspora osmophila and Gluconobacter cerinus Help to Control the Causal Agents of Gray Rot and Summer Bunch Rot of Table Grapes. Antibiotics 2021, 10, 664. https: / / doi.org/10.3390/ antibiotics10060664

Academic Editors:

Constantinos Athanassopoulos,

Carlos L. Cespedes Acuña and María Cecilia Carpinella

Received: 21 April 2021

Accepted: 24 May 2021

Published: 2 June 2021

Publisher's Note: MDPI stays neutral with regard to jurisdictional claims in published maps and institutional affiliations.

Copyright: (c) 2021 by the authors. Licensee MDPI, Basel, Switzerland. This article is an open access article distributed under the terms and conditions of the Creative Commons Attribution (CC BY) license (https:// creativecommons.org/licenses/by/ $4.0 /)$.

\begin{abstract}
Gray and summer bunch rot are important diseases of table grapes due to the high economic and environmental cost of their control with synthetic fungicides. The ability to produce antifungal compounds against the causal agents Botrytis, Aspergillus, Penicillium, and Rhizopus of two microorganisms isolated from table grapes and identified as Hanseniaspora osmophila and Gluconobacter cerinus was evaluated. In dual cultures, both biocontrol agents (together and separately) inhibited in vitro mycelial growth of these pathogens. To identify the compounds responsible for the inhibitory effect, extractions were carried out with organic solvents from biocontrol agents separately. Through dual cultures with pathogens and pure extracts, only the hexane extract from H. osmophila showed an inhibitory effect against Botrytis cinerea. To further identify these compounds, the direct bioautography technique was used. This technique made it possible to determine the band displaying antifungal activity at $\mathrm{Rf}=0.05-0.2$. The compounds present in this band were identified by GCMS and compared to the NIST library. The most abundant compounds, not previously reported, corresponded to alkanes, ketones, alcohols, and terpenoids. H. osmophila and G. cerinus have the potential to control the causal agents of gray and summer bunch rot of table grapes.
\end{abstract}

Keywords: biocontrol agents; antifungal compounds; fungal growth; in vitro inhibition

\section{Introduction}

Table grape is the most cultivated fruit species in Chile; its growth area covers $14 \%$ of the national fruit industry and the country is positioned as the main exporter worldwide [1]. Two of the most important diseases in table grape production are gray rot (B. cinerea) and bunch rot (species of the genus Aspergillus, Botrytis, Penicillium and Rhizopus) [2,3]. It is estimated that botryticides represent $10 \%$ of the world fungicide market and that the wine and table grape segment represents $50 \%$ of the total value of the botryticide market [4]. In Chile, the cost of botryticides amounts to USD 22.4 million year ${ }^{-1}$ [5]. For these reasons, B. cinerea is considered the second most important pathogen in the world [6].

It has been of particular scientific interest to investigate methods of controlling table grape bunch rot diseases. Due to the growing public interest in consuming safe food with the least possible environmental impact, restriction of fungicides, maximum residue limits and the frequent development of resistant strains of $B$. cinerea $[7,8]$ to synthetic fungicides, biological products have acquired great importance [9-12]. 
Previous works have revealed that micro fissures occur in the cuticle during grape ripening, which is colonized by oxidative or weakly fermentative ascomycetes and basidiomycetes [13]. If the berry has wounds, ascomycetes with high fermentative activity and acetic acid bacteria - transported by drosophilid insects - predominate in the released juice $[14,15]$. Within the yeasts and bacteria present in this rotting process (called bunch rot, sour rot or ripe rot), the genera Hanseniaspora and Gluconobacter consistently prevail [13-17]. While the role of the bacteria in berry rot is well known, there are very limited studies that have evaluated their biocontrol activity. Within the framework of development of new "cleaner" technologies, the Phytopathology Laboratory of the Pontificia Universidad Católica de Valparaíso has developed a biological product to control gray and summer bunch rot diseases that affect table grapes. For this, the organisms that intervene in the causative complex of both diseases were isolated, and it was found that two of them show potential to be used as biocontrol agents (BCAs), which correspond to a bacterium, Gluconobacter cerinus, and a yeast, Hanseniaspora osmophila.

Although there is evidence of the control of fungal diseases in different crops through the use of strains of the genera Gluconobacter [18] and Hanseniaspora [19-23], their biocontrol mechanisms have been poorly investigated. These mechanisms are the result of a BCApathogen-host interaction and classified in production of volatile (VOCs) and diffusible organic compounds, competition for space and nutrients, parasitism, production of lytic enzymes, and resistance induction [24,25]. Unlike VOCs, diffusible compounds are in a liquid or solid state at atmospheric temperature and pressure. Our research group has studied the VOCs produced by H. osmophila and G. cerinus on the mycelial growth of the causal agents of both diseases [26]. However, the existence of diffusible antifungal compounds is still unknown. Therefore, the following study aims: (i) to evaluate the production and effect of diffusible organic compounds produced by the BCAs on the pathogens causing gray and summer bunch rot of table grape and (ii) to identify the diffusible compounds through GC-MS.

\section{Results and Discussion}

\subsection{Morphological and Molecular Identification of Pathogens}

In this study, the phytopathogenic fungi with which we work were duly identified and sequences were deposited in GenBank as Botrytis cinerea (ITS: MT218334 and betatubulin: MT228634), Penicillium expansum (ITS: MT218335 and beta-tubulin: MT228635), Aspergillus tubingensis (ITS: MT218336 and beta-tubulin: MT228636) and Rhizopus stolonifer (ITS: MT227125).

\subsection{In Vitro Effect of Diffusible Compounds Produced by BCAs}

The mycelial growth of all pathogens was inhibited by the diffusible compounds produced by the BCAs concerning the control treatment (Figure 1). Mainly, inhibition was more significant against $B$. cinerea and P. expansum. The highest percentage of inhibition was presented in the trial with $B$. cinerea, with an average for all treatments of $86.3 \%$. In the case of P. expansum, the average inhibition percentage was $53.9 \%$.

Biocontrol activity of G. cerinus against B. cinerea have been reported [18], but its mode of action was not investigated. Studies that support the biocontrol activity are more numerous in the case of species of the genus Hanseniaspora [19-23,27-29]. Several authors have evaluated the effect of $H$. uvarum on the gray rot of grapes in vitro and in vivo using the methods of dual culture and co-inoculation in berries. Some of them were able to demonstrate that the yeast was capable of reducing (or inhibiting) spore germination and mycelial growth of the pathogen when applied alone [28] or in combination with adjuvants $[20,27,29]$. The biocontrol activity of Hanseniaspora spp. has been also associated with the induction of resistance in the berry, resulting in a decay reduction, maintenance of fruit quality parameters, and an increase in the synthesis of PR proteins $[19,20,29]$. Other authors have attributed the effect of biocontrol on possible competition mechanisms [21,22] and production of VOCs [23]. As previously reported, yeasts are promising BCAs as they 
present several advantages compared to other microorganisms [30,31]. However, a deep understanding of the action mechanism is required to develop appropriate formulation and application methods [24].

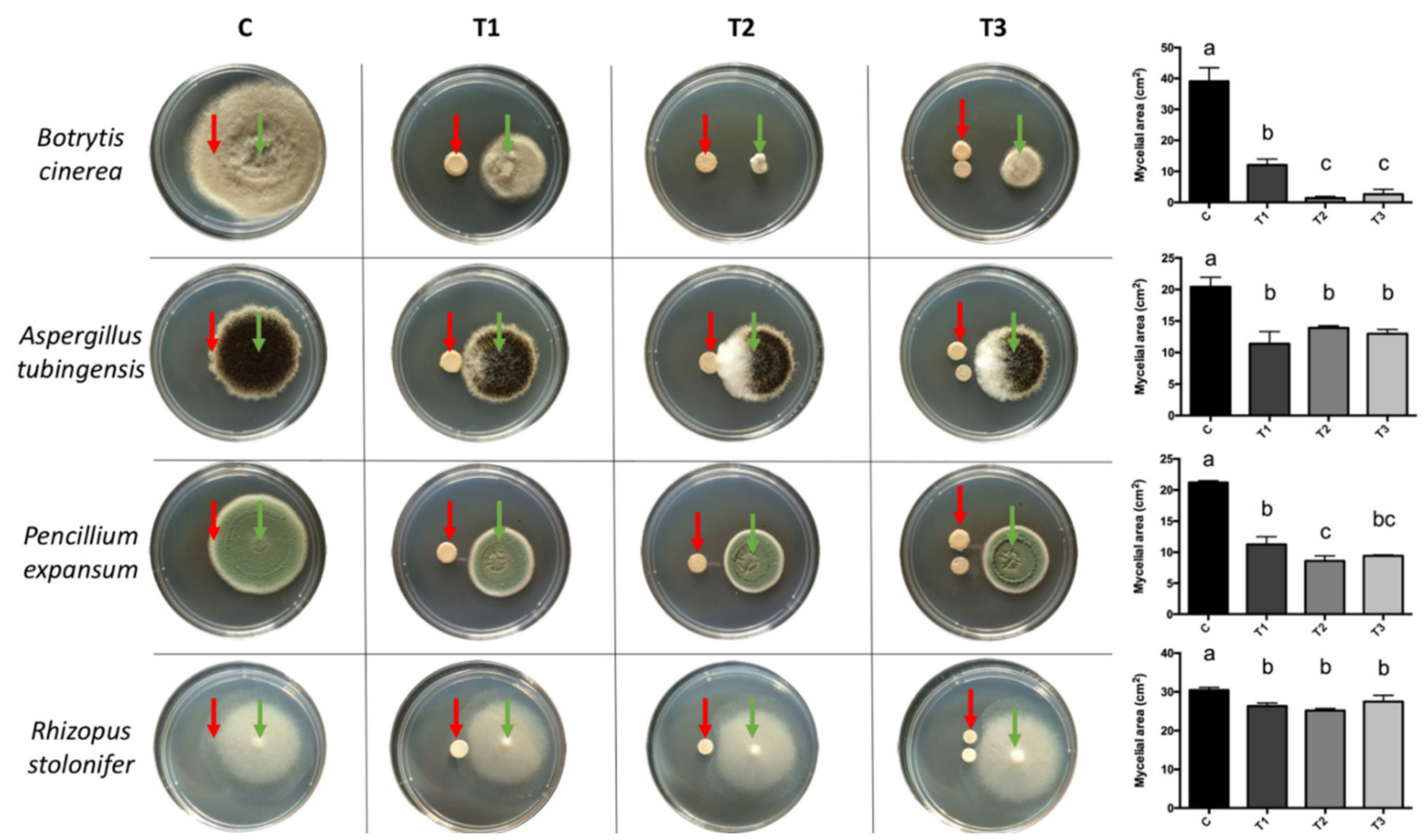

Figure 1. Dual cultures of BCAs (red arrows) with pathogens (green arrows). For all pathogens, an inoculum of $20 \mu \mathrm{L}$ was used at a concentration of $1 \times 10^{5}$ conidia $\mathrm{mL}^{-1}$. The concentration for G. cerinus was $1 \times 10^{6} \mathrm{CFU} \mathrm{mL}^{-1}$ and $1 \times 10^{4}$ cells $\mathrm{mL}^{-1}$ for H. osmophila. (C) Control: $20 \mu \mathrm{L}$ of sterile distilled water, (T1) $20 \mu \mathrm{L}$ of G. cerinus, (T2) $20 \mu \mathrm{L}$ of H. osmophila, and (T3) $10 \mu \mathrm{L}$ of G. cerinus and $10 \mu \mathrm{L}$ of H. osmophila. Vertical bars represent standard deviation and different letters indicate significant differences according to Tukey's test $(p<0.05)$.

\subsection{Extraction of Diffusible Compounds and Extract Evaluation}

In the case of extraction with organic solvents (dichloromethane and hexane) of the supernatant from the $\mathrm{BCA}$ cultures, the amount of final solute obtained from the dichloromethane extractions was $28.9 \mathrm{mg}$ ( $1.45 \%$ extraction yield) and $47.4 \mathrm{mg}(2.37 \%$ extraction yield) for G. cerinus and H. osmophila, respectively.

Regarding the evaluation of the extracts, treatments based on the dichloromethane extract of G. cerinus (T1), the dichloromethane extract of H. osmophila (T2) and the hexane extract of G. cerinus (T3) inhibited an average of 0, 5.7 and 4.5\% mycelial growth of the pathogen, respectively. The only treatment capable of significantly inhibiting the growth of B. cinerea was T4 (extract with hexane from the supernatant of $H$. osmophila) with a $38.2 \%$ inhibition on average (Figure 2). 


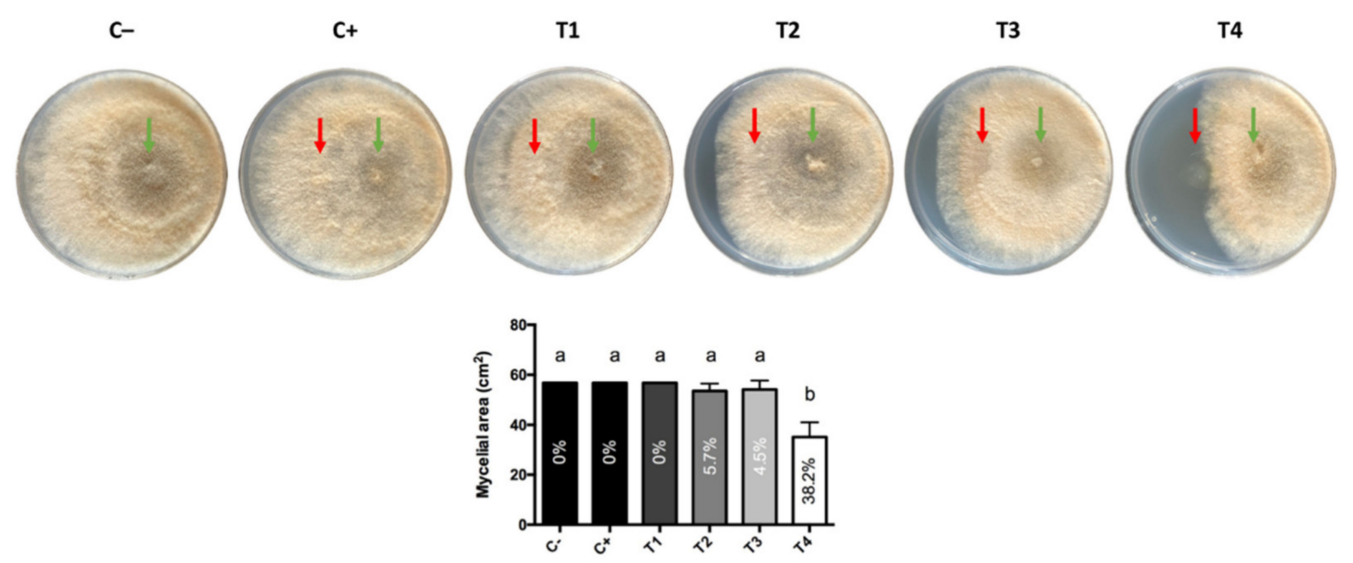

Figure 2. Effect of organic extracts (red arrows) on the mycelial growth of B. cinerea (green arrows). For B. cinerea, an inoculum of $20 \mu \mathrm{L}$ was used at a concentration of $1 \times 10^{5}$ conidia $\mathrm{mL}^{-1}$. Twenty microliters of each treatment were applied: $(\mathrm{C}-$ ) negative control (pathogen only), $(\mathrm{C}+)$ positive control (20 $\mu \mathrm{L}$ DMSO against the pathogen), (T1) dichloromethane extract of G. cerinus, (T2) dichloromethane extract of H. osmophila, (T3) hexane extract of G. cerinus, and (T4) hexane extract of $H$. osmophila. The percentages inside the bars indicate the percentage of inhibition of B. cinerea mycelial growth. Vertical bars represent standard deviation, and different letters indicate significant differences according to Tukey's test $(p<0.05)$.

\subsection{Separation and Evaluation of the Extract}

Development with $20 \%$ sulfuric acid $\left(\mathrm{H}_{2} \mathrm{SO}_{4}\right)$ showed a band near the starting point defined bands (Figure $3 \mathrm{~A}$ ) and bioautography allowed this band, displaying no growth of $B$. cinerea (Figure 3B). Compounds should be mostly non-polar as the retention factor value (Rf) of the band was 0.05 to 0.2 . This band was subsequently analyzed by GC-MS to identify the compounds present.
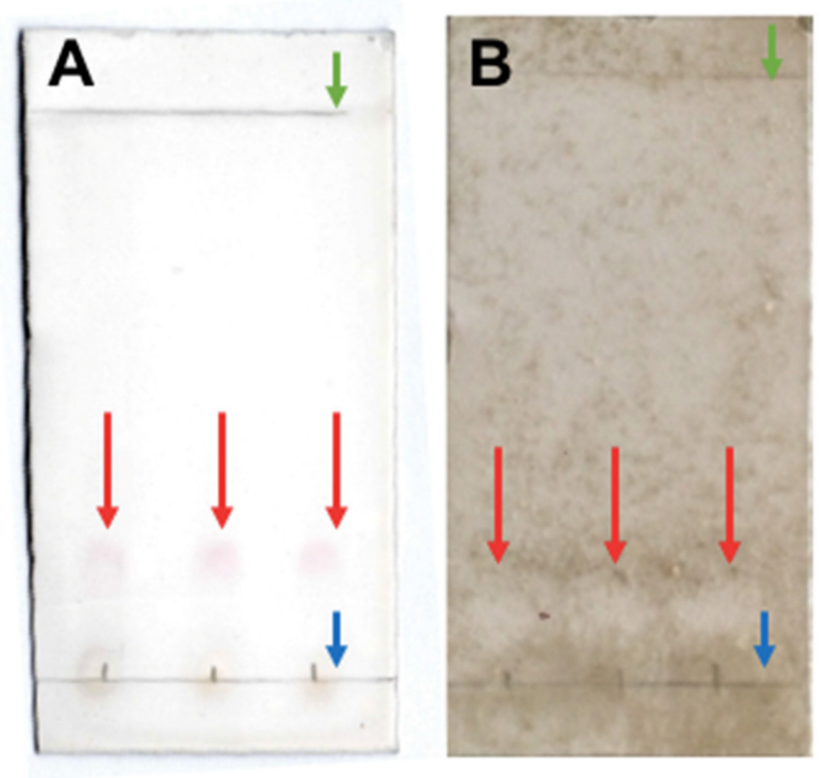

Figure 3. Chromatographic plates of hexane extract from H. osmophila culture with mobile phase Hex: EtOAc (6: 1). The chromatographic plates show three lanes as replicates. (A) TLC plate developed with $20 \% \mathrm{H}_{2} \mathrm{SO}_{4}$ where red arrows indicate revealed compounds; and (B) Results for the direct bioautography assay where red arrows indicate growth inhibition of B. cinerea at $\mathrm{Rf}=0.05$ to 0.2 . Green arrows indicate the solvent front and blue arrows indicate the starting point. 


\subsection{Identification of the Active Compounds of the Extract}

GC-MS identification revealed that 29 compounds (66.7\% of the total amount present in the sample) were detected in the hexane extract, of which 13 have been reported with antifungal or antibacterial activity in the literature (Table 1). The most abundant group corresponded to alkanes representing $25.5 \%$ of the total and correlating with the low migration of compounds in the direct autobiography assay. Previous studies have shown the antifungal activity of tetra- and pentadecane [32] and eicosane and heneicosane [33,34]. Very long-chain alkanes were found to inhibit multiple targets of important pathogenic proteins and enzymes [35]. The second group that appeared in a more significant quantity corresponded to ketones, with 24.1\%. 3-methyl-2-butanone [36], 3-pentanone [37], and 4-hydroxy-4-methyl-2-pentanone [38] have also been reported as antifungal compounds, but their mechanism of action remains unknown. Alcohols occupied third place with 15.8\% representation. Mannaa and Kim [39] identified 2-isopropyl-5-methylheptanol and 2butyloctanol in the filtrate of the Pseudomonas protegens culture with activity against species of the genera Aspergillus and Penicillium. Terpenoids were the fourth group, with $15.4 \%$ of the total composition. Squalene is the compound that occurred individually in greater abundance in the hexane extract. It is a terpene that contains six isoprene units and is known to be the first specific precursor of ergosterol [40]. Then, the esters followed in fifth place with $6.4 \%$. Huang et al. [41] observed that the propanoic acid ethyl ester or ethyl propionate was produced by Candida intermedia and inhibited the mycelial growth of $B$. cinerea by the double-plate method. In sixth place were fatty acids with $4.6 \%$. Zhang et al. [42] identified (Z)-13-docosenamide as one of the four key biocontrol components produced by Trichoderma longibrachiatum against $B$. cinerea, $A$. niger, and $R$. nigricans. Likewise, this compound was the most abundant among those produced by a biocontrol strain of Streptomyces sp. [43].

Table 1. Compounds identified by GC-MS from the hexane extract of H. osmophila.

\begin{tabular}{|c|c|c|c|c|c|c|c|c|}
\hline $\mathbf{N}^{\circ}$ Peak & RT (Min) & Main Components & $\mathbf{R I}+$ & RIref $\ddagger$ & \%Area & Match & Activity $\S$ & Reference \\
\hline 1 & 4.03 & 2-Butanone, 3-methyl- & 590 & 650 & 5.11 & 90 & anf & [36] \\
\hline 2 & 4.13 & 3-Pentanone & 654 & 672 & 4.01 & 91 & anf & [37] \\
\hline 3 & 4.30 & Propanoic acid, ethyl ester & 686 & 693 & 2.08 & 81 & anf & [41] \\
\hline 4 & 6.60 & $\begin{array}{c}\text { 2-Pentanone, } \\
\text { 4-hydroxy-4-methyl- }\end{array}$ & 845 & 811 & 6.91 & 89 & $\mathrm{anb} / \mathrm{anf}$ & [38] \\
\hline 5 & 10.37 & Hexanoic acid & 974 & 950 & 0.69 & 92 & anf & [44] \\
\hline 6 & 12.66 & Undecane & 1115 & 1100 & 2.04 & 93 & NR & \\
\hline 7 & 14.89 & Dodecane, 4,6-dimethyl- & 1285 & 1325 & 0.87 & 87 & NR & \\
\hline 8 & 15.78 & 1-Octanol, 2-butyl- & 1393 & 1277 & 1.88 & 90 & anf & [39] \\
\hline 9 & 15.91 & 11-Methyldodecanol & 1492 & 1435 & 2.76 & 89 & NR & \\
\hline 10 & 16.03 & 2-Isopropyl-5-methyl-1-heptanol & 1165 & 1165 & 2.50 & 88 & anf & [39] \\
\hline 11 & 17.15 & Tetradecane & 1413 & 1400 & 2.57 & 98 & $\mathrm{anb} / \mathrm{anf}$ & {$[32,33]$} \\
\hline 12 & 17.90 & $\begin{array}{c}\text { Hexadecane, } \\
\text { 2,6,11,15-tetramethyl- }\end{array}$ & 1753 & 1792 & 4.24 & 84 & NR & \\
\hline 13 & 18.25 & Tetradecane, 4-methyl- & 1448 & 1454 & 0.56 & 84 & NR & \\
\hline 14 & 18.45 & Pentadecane & 1512 & 1500 & 1.59 & 97 & $\mathrm{anb} / \mathrm{anf}$ & {$[32]$} \\
\hline 15 & 18.60 & 2,4-Di-tert-butylphenol & 1555 & 1519 & 0.95 & 92 & anf & [45] \\
\hline 16 & 19.02 & 1-Dodecanol, 2-hexyl- & 1989 & 1504 & 1.04 & 81 & NR & \\
\hline 17 & 19.68 & Hexadecane & 1612 & 1600 & 1.67 & 97 & NR & \\
\hline 18 & 20.84 & Octadecane & 1810 & 1800 & 1.39 & 94 & NR & \\
\hline 19 & 21.49 & 1-Heptanol, 2,4-diethyl- & 1229 & 1229 & 2.33 & 87 & NR & \\
\hline 20 & 22.93 & Eicosane & 2009 & 2000 & 0.59 & 82 & $\mathrm{anb} / \mathrm{anf}$ & [34] \\
\hline 21 & 23.01 & 2-Methylhexacosane & 2656 & 2656 & 0.95 & 83 & NR & \\
\hline
\end{tabular}


Table 1. Conts.

\begin{tabular}{|c|c|c|c|c|c|c|c|c|}
\hline $\mathbf{N}^{\circ}$ Peak & RT (Min) & Main Components & $\mathbf{R I}+$ & RIref $\ddagger$ & $\%$ Area & Match & Activity $\S$ & Reference \\
\hline 22 & 23.13 & $\begin{array}{c}\text { 1H-Indole-3-ethanol, acetate } \\
\text { (ester) }\end{array}$ & 1729 & 1926 & 1.70 & 88 & NR & \\
\hline 23 & 23.18 & $\begin{array}{c}\text { 7,9-Di-tert-butyl-1- } \\
\text { oxaspiro(4,5)deca-6,9-diene-2,8- } \\
\text { dione }\end{array}$ & 2081 & 1929 & 1.23 & 85 & NR & \\
\hline 24 & 23.99 & Heneicosane & 2109 & 2100 & 0.51 & 89 & anb/anf & {$[33,34]$} \\
\hline 25 & 26.72 & $\begin{array}{l}\text { Carbonic acid, octadecyl } \\
\text { prop-1-en-2-yl ester }\end{array}$ & 2189 & 2189 & 0.50 & 85 & NR & \\
\hline 26 & 27.57 & $\begin{array}{c}\text { Ethanol, 2-butoxy-', phosphate } \\
(3: 1)\end{array}$ & 2363 & 2363 & 2.80 & 94 & NR & \\
\hline 27 & 28.85 & $\begin{array}{c}\text { Phenol, } \\
\text { 2,4-bis(1-methyl-1-phenylethyl)- }\end{array}$ & 2702 & 2527 & 0.50 & 86 & NR & \\
\hline 28 & 32.35 & 13-Docosenamide, $(Z)-$ & 2625 & 2625 & 2.38 & 93 & anf & {$[42,43]$} \\
\hline 29 & 32.89 & Squalene & 2914 & 2847 & 10.28 & 97 & NR & \\
\hline
\end{tabular}

† RI Retention index relative to C8-C36 n-alkanes in a SLB-5ms capillary column; $\ddagger$ RIref: Retention index reported in the literature; $\S$ Activity reported in the literature: NR (no reference), anf (antifungal) and/or anb (antibacterial).

On the other hand, Leyva et al. [44] demonstrated the in vitro effectiveness of hexanoic acid in inhibiting the germination of conidia and the mycelial growth of $B$. cinerea, and of reducing the diameter of the lesion caused by the pathogen in tomato plants in a preventive and curative manner. These authors suggested an increase in membrane permeability of the pathogen as an active mechanism. In seventh place with $4.2 \%$ was an organophosphorus compound, tris (2-butoxy ethyl) phosphate, which has not been reported in the literature to have antimicrobial or antifungal activity. Finally, benzenes and lactones with $2.2 \%$ and $1.9 \%$, respectively. 2,4-di-tert-butyl-phenol has been studied for its antifungal and antioxidant activity [45]. Its modes of action have also been associated with the prevention of spore germination and reduction in mycelial growth [46]. In addition, Raza et al. [47] demonstrated a synergistic effect among the compounds produced by BCAs, thus improving the effect when applying them together.

\section{Materials and Methods}

\subsection{Morphological and Molecular Identification of Pathogens}

The BCAs were obtained from the Phytopathology Laboratory of the Pontificia Universidad Católica de Valparaíso (deposited in the Chilean Collection of Microbial Genetic Resources as G. cerinus strain 515, access code RGM2215 and H. osmophila strain 337, access code RGM2214). Pathogens were isolated from table grape cv. Red Globe and identified by observing the morphology of colonies (color and texture) and microscopic reproductive structures. For the yeast $H$. osmophila, a HPA medium $\left(80 \mathrm{~g} \mathrm{~L}^{-1}\right.$ honey, $20 \mathrm{~g} \mathrm{~L}^{-1}$ peptone and $20 \mathrm{~g} \mathrm{~L}^{-1}$ agar) was used [48]. G. cerinus was cultured and maintained on MYP medium (25 g L -1 mannitol, $5 \mathrm{~g} \mathrm{~L}^{-1}$ yeast extract, $3 \mathrm{~g} \mathrm{~L}^{-1}$ peptone and $12 \mathrm{~g} \mathrm{~L}^{-1}$ agar) [49] and PDA $\left(\right.$ Difco $\left.^{\mathrm{TM}}\right)$ was used for all fungal pathogens.

Pathogens were further identified by molecular methods. Sequences were deposited in GenBank as Botrytis cinerea (ITS: MT218334 and beta-tubulin: MT228634), Penicillium expansum (ITS: MT218335 and beta-tubulin: MT228635), Aspergillus tubingensis (ITS: MT218336 and beta-tubulin: MT228636) and Rhizopus stolonifer (ITS: MT227125).

\subsection{In Vitro Effect of Diffusible Organic Compounds Produced by the BCAs on the Pathogenic Fungi}

The pathogenic fungi were grown in Petri dishes with PDA medium by seeding a plug of agar with mycelium in active growth. Rhizopus stolonifer was incubated at $25^{\circ} \mathrm{C}$ for three days; $B$. cinerea at $25^{\circ} \mathrm{C}$ for seven days under UV-A light $(\lambda=350 \mathrm{~nm})$; Penicillium expansum and Aspergillus tubingensis for seven days at $25^{\circ} \mathrm{C}$. From these plates, the conidia were removed, and a suspension was prepared with sterile distilled water (SDW) at a concentration of $1 \times 10^{5}$ conidia $\mathrm{mL}^{-1}$. 
Biocontrol agents were grown in Petri dishes in their respective media and incubated at $25{ }^{\circ} \mathrm{C}$ for five days. Spores were removed, and a suspension at a concentration of $1 \times 10^{4}$ cells $\mathrm{mL}^{-1}$ for the yeast was prepared using a hematocytometer (NeubauerImpr. Counting chamber, Hirschmann, Germany). Similarly, concentration of the bacterial suspension was adjusted to $1 \times 10^{6} \mathrm{CFU} \mathrm{mL}^{-1}$ using a spectrophotometer at an $\mathrm{OD}_{580 \mathrm{~nm}}$ (BOECO S-300, Hamburg, Germany).

One centimeter from the center of a PDA plate, $20 \mu \mathrm{L}$ of the biocontrollers and $20 \mu \mathrm{L}$ of the pathogens were inoculated in the opposite direction. The treatments consisted of facing each of the BCAs (separately and together) against each pathogenic fungus. As a control treatment, SDW was used against each of the pathogenic fungi. The plates were incubated at $25{ }^{\circ} \mathrm{C}$ for three days for $R$. stolonifer and at $25^{\circ} \mathrm{C}$ for seven days for the rest of the pathogens. In order to evaluate the experiment, photographs of the plates were taken and the area of the mycelium was measured using the software Image ${ }^{\circledR}(\mathrm{NIH}$, Bethesda, MD, USA). The percentage of inhibition of each treatment was calculated by the following equation: $\mathrm{PI}=((\mathrm{CA}-\mathrm{TA}) / \mathrm{CA}) \times 100$, where PI: percent inhibition; $\mathrm{CA}$ : average control treatment; TA: treatment average. The experimental unit was each Petri dish, and the experimental design was completely randomized with three replicates. The experiment was repeated three times.

\subsection{Extraction of Diffusible Compounds and Evaluation of Extracts}

The BCAs were cultured separately using liquid medium sucrose yeast nitrogen (SYN) (20 $\mathrm{g} \mathrm{L}^{-1}$ sucrose, $10 \mathrm{~g} \mathrm{~L}^{-1}$ yeast extract, and $1 \mathrm{~g} \mathrm{~L}^{-1}$ ammonium chloride, adjusted to pH 5 with $\mathrm{HCl}$ and $10 \mathrm{M} \mathrm{NaOH}$ ) in a $3 \mathrm{~L}$ bioreactor (Applikon ${ }^{\circledR}$ Biotechnology, Schiedam, The Netherlands) equipped with a mass flow controller for air, $\mathrm{pH}$ and temperature. The bioreactor conditions for the growth of the BCAs were the following: 400 rpm agitation, $1 \mathrm{vvm}$ aeration, $\mathrm{pH} 5$ and $25^{\circ} \mathrm{C}$. The BCAs were previously cultured in Luria-Bertani medium (10 $\mathrm{g} \mathrm{L}^{-1}$ peptone, $5 \mathrm{~g} \mathrm{~L}^{-1}$ yeast extract and $5 \mathrm{~g} \mathrm{~L}^{-1}$ sodium chloride) and then inoculated at $10 \% \mathrm{v} \mathrm{v}^{-1}$ in $2 \mathrm{~L}$ of SYN medium. The culture was harvested in the late exponential phase and centrifuged at $2370 \mathrm{~g}$ for $10 \mathrm{~min}$ using a centrifuge (Hettich Universal 320, Tuttlingen, Germany) to separate the precipitate from the supernatant. In a separatory funnel, the supernatant was mixed with a stirrer and an organic solvent of low polarity (hexane, Merck LiChrosolv, Darmstadt, Germany) and one of medium polarity (dichloromethane, PanReac Applichem ITW Reagents, Barcelona, Spain) were introduced. Subsequently, the organic solvent was transferred to an evaporation flask and evaporated using a rotary evaporator (Buchi R-300, Zurich, Switzerland) at $30{ }^{\circ} \mathrm{C}$ and $200 \mathrm{rpm}$. To extract the solid fraction from the flask, three milliliters of dichloromethane were added, then the solution was removed with a micropipette and placed in a $50 \mathrm{~mL}$ glass jar and left under an extraction hood until the solvent was completely evaporated. Finally, $1 \mathrm{~mL}$ of dimethylsulfoxide (DMSO, Merck, Darmstadt, Germany) was added, and the resulting solutions were kept at $4{ }^{\circ} \mathrm{C}$ until the new test was started.

To evaluate the effect of the extracts, the dual culture method described above was used, but replacing the BCAs inoculum with its corresponding extract. Additionally, the extracts were evaluated only against $B$. cinerea. The treatments corresponded to $20 \mu \mathrm{L}$ of each extract: T1) dichloromethane extract of G. cerinus, T2) dichloromethane extract of $H$. osmophila, T3) hexane extract of G. cerinus and T4) hexane extract of H. osmophila. The same volume of DMSO was used as control. Five replicates were used per treatment, and the test was repeated three times.

\subsection{Separation and Evaluation of the Extract}

After the evaluation of extracts, the one with the highest activity (hexane extract from the culture supernatant of $H$. osmophila) was separated by thin-layer chromatography. A silica gel plate $(2.5 \mathrm{~cm}$ wide and $5 \mathrm{~cm}$ long) was used as the stationary phase and a mixture of Hex: EtOAc (6:1) as the mobile phase. As revealers, UV light with a wavelength of $312 \mathrm{~nm}$ (Vilber Lourmat ETX-20.M, Germany) and submersion in a solution of $20 \%$ sulfuric acid $\left(\mathrm{H}_{2} \mathrm{SO}_{4}\right)$ 
followed by drying on a heating plate at $100{ }^{\circ} \mathrm{C}$ were used. After separation, the effect of the separated compounds was evaluated by direct bioautography [50]. Briefly, the conidia were extracted from a 7-day PDA plate using a loop previously submerged in Tween 20 and suspended in SDW until reaching a concentration of $1 \times 10^{7}$ conidia $\mathrm{mL}^{-1}$. This conidia suspension was mixed 1:100 with PDB to obtain a final concentration of $1 \times 10^{5}$ conidia $\mathrm{mL}^{-1}$. Chromatographic plates not revealed with sulfuric acid were immersed in this nutrient suspension and incubated at $25{ }^{\circ} \mathrm{C}$ for seven days in a humid chamber. Subsequently, photographs were taken, and the Rf was calculated using Image $J^{\circledR}$ software.

\subsection{Identification of Extract Active Compounds}

The band that showed the highest inhibitory effect was scraped from the chromatographic plate and mixed with $1 \mathrm{~mL}$ of acetonitrile (LiChrosolv, Merck, Darmstadt, Germany). This solution was separated and its components were identified by a gas chromatograph/mass spectrometry (GCMS-QP2010 Ultra, Shimadzu Corp., Kyoto, Japan). The conditions of the technique were: SLB-5ms capillary column $30 \mathrm{~m} \times 0.25 \mathrm{~mm} \times 0.25 \mu \mathrm{m}$ (Supelco, Milan, Italy); helium carrier gas flow at $1 \mathrm{~mL} \mathrm{~min}^{-1}$; injection temperature at $250{ }^{\circ} \mathrm{C}$; oven temperature program: $40^{\circ} \mathrm{C}$ for $4 \mathrm{~min}, 10^{\circ} \mathrm{C} \mathrm{min}-1$ to $270{ }^{\circ} \mathrm{C}$ and hold for

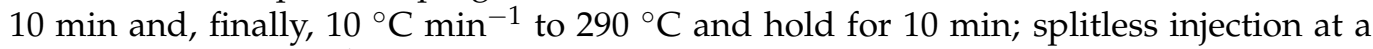
volume of $1 \mu \mathrm{L} \mathrm{min}^{-1}$ using a Shimadzu AOC-20i auto injector. The compounds of the extract were identified by comparison with the NIST 2014 database (applying $>80 \%$ match as acceptance requirement).

\subsection{Statistical Analysis}

Data obtained from the tests were subjected to an analysis of variance $(p<0.05)$ and a Tukey test $(p<0.05)$ was performed in case of significant differences using GraphPad Prism ${ }^{\circledR}$ software (GraphPad Software Inc. v. 6, San Diego, CA, USA).

\section{Conclusions}

The BCAs Hanseniaspora osmophila and Gluconobacter cerinus were able to inhibit the mycelial growth of all the pathogens used by the production of diffusible organic compounds. The highest percentage of inhibition was observed against $B$. cinerea. Of the extracts used, only hexane extraction from the liquid culture with H. osmophila significantly inhibited the growth of $B$. cinerea. By thin-layer chromatography, the components of the extract were separated, and the compounds present in a band with antifungal effects were identified using the bioautography technique. Fifty-five percent of the detected compounds have not been reported as antifungal or antibacterial in the literature. Future work can be conducted to elucidate the role of these molecules in the mycelial growth or spore germination of this pathogen.

\section{Patents}

Patent $N^{\circ}$ 61580, 7 January 2021, WO2017088081A1.

Author Contributions: Conceptualization, M.O. and X.B.; methodology, M.O., N.D., F.C., N.R., I.M., R.P. and X.B.; writing—original draft preparation, M.O., N.D., F.C., G.B., I.M., N.R., M.S., W.B.-P., R.P. and X.B.; writing-review and editing, M.O., N.D., F.C., G.B., I.M., N.R., M.S., W.B.-P., R.P. and X.B.; visualization, M.O. and X.B.; supervision, X.B.; funding acquisition, X.B. and F.C. All authors have read and agreed to the published version of the manuscript.

Funding: This research was funded by project ID17AL0028, funded by FONDEF from Chile's government and ANASAC Chile.

Acknowledgments: The authors thank FONDEQUIP EQM140074 and EQM170194, Araceli Vidal for helping to design the thin layer chromatography methodology and Alejandro Villarreal for helping with the translations.

Conflicts of Interest: Two of the co-authors who participated in this study (Fabiola Cádiz and Ximena Besoain) are co-inventors of a biological product based on the microorganisms used (Hanseniaspora 
osmophila and Gluconobacter cerinus) to prevent rot in grapes. It has been requested to patent this product (WO2017088081A1). In addition, the principal author and two co-authors (Ninoska Delgado and Guillermo Bravo) have an indirect (honorary) financial relationship with the FONDEF ID17AL0028 project, which seeks to develop a commercial formulation of the product.

\section{References}

1. CIREN-ODEPA. Catastro Frutícola Región del Maule; Larrañaga, P., Osores, M.A., Eds.; ODEPA: Santiago, Chile, $2019 ;$ p. 48.

2. Duncan, R.A.; Stapleton, J.J.; Leavitt, G.M. Population dynamics of epiphytic mycoflora and occurrence of bunch rots of wine grapes as influenced by leaf removal. Plant Pathol. 1995, 44, 956-965. [CrossRef]

3. Williamson, B.; Tudzynski, B.; Tudzynski, P.; Van Kan, J.A.L. Botrytis cinerea: The cause of grey mould disease. Mol. Plant Pathol. 2007, 8, 561-580. [CrossRef]

4. Fillinger, S.; Walker, A.S. Chapter 10: Chemical control and resistance management of Botrytis diseases. In Botrytis-The Fungus, the Pathogen and Its Management in Agricultural Systems; Fillinger, S., Elad, Y., Eds.; Springer: New York, NY, USA, 2015; pp. 1-486. ISBN 9783319233710.

5. Esterio, M.; Auger, J.; Ramos, C.; Walker, A.; Muñoz, G.; Fillinger, S. Botrytis en uva de mesa de exportación: Situación actual de sensibilidad a fungicidas en Chile. Aconex 2009, 103, 16-23.

6. Dean, R.; Van Kan, J.A.L.; Pretorius, Z.A.; Hammond-Kosack, K.E.; Di Pietro, A.; Spanu, P.D.; Rudd, J.J.; Dickman, M.; Kahmann, R.; Ellis, J.; et al. The Top 10 fungal pathogens in molecular plant pathology. Mol. Plant Pathol. 2012, 13, 414-430. [CrossRef]

7. Latorre, B.A.; Spadaro, I.; Rioja, M.E. Occurrence of resistant strains of Botrytis cinerea to anilinopyrimidine fungicides in table grapes in Chile. Crop Prot. 2002, 21, 957-961. [CrossRef]

8. Latorre, B.A.; Torres, R. Prevalence of isolates of Botrytis cinerea resistant to multiple fungicides in Chilean vineyards. Crop Prot. 2012, 40, 49-52. [CrossRef]

9. Aoki, T.; Aoki, Y.; Ishiai, S.; Otoguro, M.; Suzuki, S. Impact of Bacillus cereus NRKT on grape ripe rot disease through resveratrol synthesis in berry skin. Pest Manag. Sci. 2017, 73, 174-180. [CrossRef] [PubMed]

10. Carbó, A.; Torres, R.; Usall, J.; Marín, A.; Chiralt, A.; Teixidó, N. Novel film-forming formulations of the biocontrol agent Candida sake CPA-1: Biocontrol efficacy and performance at field conditions in organic wine grapes. Pest Manag. Sci. 2019, 75, 959-968. [CrossRef] [PubMed]

11. Calvo-Garrido, C.; Viñas, I.; Elmer, P.A.; Usall, J.; Teixidó, N. Suppression of Botrytis cinerea on necrotic grapevine tissues by early-season applications of natural products and biological control agents. Pest Manag. Sci. 2014, 70, 595-602. [CrossRef] [PubMed]

12. Rotolo, C.; De Miccolis Angelini, R.M.; Dongiovanni, C.; Pollastro, S.; Fumarola, G.; Di Carolo, M.; Perrelli, D.; Natale, P.; Faretra, F. Use of biocontrol agents and botanicals in integrated management of Botrytis cinerea in table grape vineyards. Pest Manag. Sci. 2018, 74, 715-725. [CrossRef]

13. Barata, A.; Malfeito-Ferreira, M.; Loureiro, V. The microbial ecology of wine grape berries. Int. J. Food Microbiol. 2012, 153, 243-259. [CrossRef]

14. Barata, A.; Santos, S.C.; Malfeito-Ferreira, M.; Loureiro, V. New Insights into the Ecological Interaction Between Grape Berry Microorganisms and Drosophila Flies During the Development of Sour Rot. Microb. Ecol. 2012, 64, 416-430. [CrossRef] [PubMed]

15. Barata, A.; Malfeito-Ferreira, M.; Loureiro, V. Changes in sour rotten grape berry microbiota during ripening and wine fermentation. Int. J. Food Microbiol. 2012, 154, 152-161. [CrossRef]

16. Mateo, E.; Torija, M.J.; Mas, A.; Bartowsky, E.J. Acetic acid bacteria isolated from grapes of South Australian vineyards. Int. J. Food Microbiol. 2014, 178, 98-106. [CrossRef]

17. Valera, M.J.; Laich, F.; González, S.S.; Torija, M.J.; Mateo, E.; Mas, A. Diversity of acetic acid bacteria present in healthy grapes from the Canary Islands. Int. J. Food Microbiol. 2011, 151, 105-112. [CrossRef]

18. Guzzon, R.; Franciosi, E.; Larcher, R. A new resource from traditional wines: Characterization of the microbiota of "vino santo" grapes as a biocontrol agent against botrytis cinerea. Eur. Food Res. Technol. 2014, 239, 117-126. [CrossRef]

19. Cai, Z.; Yang, R.; Xiao, H.; Qin, X.; Si, L. Effect of preharvest application of Hanseniaspora uvarum on postharvest diseases in strawberries. Postharvest Biol. Technol. 2015, 100, 52-58. [CrossRef]

20. Qin, X.; Xiao, H.; Xue, C.; Yu, Z.; Yang, R.; Cai, Z.; Si, L. Biocontrol of gray mold in grapes with the yeast Hanseniaspora uvarum alone and in combination with salicylic acid or sodium bicarbonate. Postharvest Biol. Technol. 2015, 100, 160-167. [CrossRef]

21. Li, W.; Zhang, H.; Li, P.; Apaliya, M.T.; Yang, Q.; Peng, Y.; Zhang, X. Biocontrol of postharvest green mold of oranges by Hanseniaspora uvarum Y3 in combination with phosphatidylcholine. Biol. Control 2016, 103, 30-38. [CrossRef]

22. Prendes, L.P.; Merín, M.G.; Fontana, A.R.; Bottini, R.A.; Ramirez, M.L.; Morata de Ambrosini, V.I. Isolation, identification and selection of antagonistic yeast against Alternaria alternata infection and tenuazonic acid production in wine grapes from Argentina. Int. J. Food Microbiol. 2018, 266, 14-20. [CrossRef]

23. Qin, X.; Xiao, H.; Cheng, X.; Zhou, H.; Si, L. Hanseniaspora uvarum prolongs shelf life of strawberry via volatile production. Food Microbiol. 2017, 63, 205-212. [CrossRef]

24. Spadaro, D.; Droby, S. Development of biocontrol products for postharvest diseases of fruit: The importance of elucidating the mechanisms of action of yeast antagonists. Trends Food Sci. Technol. 2016, 47, 39-49. [CrossRef]

25. Köhl, J.; Kolnaar, R.; Ravensberg, W.J. Mode of action of microbial biological control agents against plant diseases: Relevance beyond efficacy. Front. Plant Sci. 2019, 10, 845. [CrossRef] 
26. Delgado, N.; Olivera, M.; Cádiz, F.; Montenegro, I.; Madrid, A.; Bravo, G.; Fuentealba, C.; Pedreschi, R.; Salgado, E.; Besoain, X. Volatile Organic Compounds (VOCs) produced by Gluconobacter cerinus and Hanseniaspora osmophila displaying control effect against table grape-rot pathogens. In Proceedings of the XXVII Congreso SOCHIFIT, Arica, Chile, 5-7 November 2019.

27. Liu, H.M.; Guo, J.H.; Cheng, Y.J.; Liu, P.; Long, C.A.; Deng, B.X. Inhibitory activity of tea polyphenol and Hanseniaspora uvarum against Botrytis cinerea infections. Lett. Appl. Microbiol. 2010, 51, 258-263. [CrossRef]

28. Liu, H.M.; Guo, J.H.; Cheng, Y.J.; Luo, L.; Liu, P.; Wang, B.Q.; Deng, B.X.; Long, C.A. Control of gray mold of grape by Hanseniaspora uvarum and its effects on postharvest quality parameters. Ann. Microbiol. 2010, 60, 31-35. [CrossRef]

29. Liu, H.M.; Guo, J.H.; Luo, L.; Liu, P.; Wang, B.Q.; Cheng, Y.J.; Deng, B.X.; Long, C.A. Improvement of Hanseniaspora uvarum biocontrol activity against gray mold by the addition of ammonium molybdate and the possible mechanisms involved. Crop Prot. 2010, 29, 277-282. [CrossRef]

30. Nadai, C.; Fernandes Lemos, W.J.; Favaron, F.; Giacomini, A.; Corich, V. Biocontrol activity of Starmerella bacillaris yeast against blue mold disease on apple fruit and its effect on cider fermentation. PLoS ONE 2018, 13, e204350. [CrossRef]

31. Parafati, L.; Vitale, A.; Restuccia, C.; Cirvilleri, G. Biocontrol ability and action mechanism of food-isolated yeast strains against Botrytis cinerea causing post-harvest bunch rot of table grape. Food Microbiol. 2015, 47, 85-92. [CrossRef]

32. Yuan, J.; Raza, W.; Shen, Q.; Huang, Q. Antifungal activity of Bacillus amyloliquefaciens NJN-6 volatile compounds against Fusarium oxysporum f. sp. cubense. Appl. Environ. Microbiol. 2012, 78, 5942-5944. [CrossRef]

33. Boussaada, O.; Saidana, D.; Chriaa, J.; Chraif, I.; Mahjoub, M.A.; Mighri, Z.; Daami, M.; Helal, A.N. Chemical composition and antimicrobial activity of volatile components of Scorzonera undulata. J. Essent. Oil Res. 2008, 20, 358-362. [CrossRef]

34. Kordali, S.; Cakir, A.; Akcin, T.A.; Mete, E.; Akcin, A.; Aydin, T.; Kilic, H. Antifungal and herbicidal properties of essential oils and n-hexane extracts of Achillea gypsicola Hub-Mor. and Achillea biebersteinii Afan. (Asteraceae). Ind. Crops Prod. 2009, 29, 562-570. [CrossRef]

35. Bordoloi, M.; Saikia, S.; Bordoloi, P.K.; Kolita, B.; Dutta, P.P.; Bhuyan, P.D.; Dutta, S.C.; Rao, P.G. Isolation, characterization and antifungal activity of very long chain alkane derivatives from Cinnamomum obtusifolium, Elaeocarpus lanceifolius and Baccaurea sapida. J. Mol. Struct. 2017, 1142, 200-210. [CrossRef]

36. Garbeva, P.; Hordijk, C.; Gerards, S.; de Boer, W. Volatiles produced by the mycophagous soil bacterium Collimonas. FEMS Microbiol. Ecol. 2014, 87, 639-649. [CrossRef] [PubMed]

37. Qadri, M.; Deshidi, R.; Shah, B.A.; Bindu, K.; Vishwakarma, R.A.; Riyaz-Ul-Hassan, S. An endophyte of Picrorhiza kurroa Royle ex. Benth, producing menthol, phenylethyl alcohol and 3-hydroxypropionic acid, and other volatile organic compounds. World $J$. Microbiol. Biotechnol. 2015, 31, 1647-1654. [CrossRef] [PubMed]

38. Zhang, J.W.; Li, S.K.; Wu, W.J. The main chemical composition and in vitro antifungal activity of the essential oils of Ocimum basilicum Linn. var. pilosum (Willd.) Benth. Molecules 2009, 14, 273-278. [CrossRef]

39. Mannaa, M.; Kim, K.D. Biocontrol activity of volatile-producing Bacillus megaterium and Pseudomonas protegens against Aspergillus and Penicillium spp. predominant in stored rice grains: Study II. Mycobiology 2018, 46, 52-63. [CrossRef] [PubMed]

40. Mantzouridou, F.; Naziri, E.; Tsimidou, M.Z. Squalene versus ergosterol formation using Saccharomyces cerevisiae: Combined effect of oxygen supply, inoculum size, and fermentation time on yield and selectivity of the bioprocess. J. Agric. Food Chem. 2009, 57, 6189-6198. [CrossRef] [PubMed]

41. Huang, R.; Li, G.Q.; Zhang, J.; Yang, L.; Che, H.J.; Jiang, D.H.; Huang, H.C. Control of postharvest Botrytis fruit rot of strawberry by volatile organic compounds of Candida intermedia. Phytopathology 2011, 101, 859-869. [CrossRef]

42. Zhang, S.; Xu, B.; Zhang, J.; Gan, Y. Identification of the antifungal activity of Trichoderma longibrachiatum T6 and assessment of bioactive substances in controlling phytopathgens. Pestic. Biochem. Physiol. 2018, 147, 59-66. [CrossRef]

43. Qi, D.; Zou, L.; Zhou, D.; Chen, Y.; Gao, Z.; Feng, R.; Zhang, M.; Li, K.; Xie, J.; Wang, W. Taxonomy and broad-spectrum antifungal activity of Streptomyces sp. SCA3-4 isolated from rhizosphere soil of Opuntia stricta. Front. Microbiol. 2019, 10, 1390. [CrossRef] [PubMed]

44. Leyva, M.O.; Vicedo, B.; Finiti, I.; Flors, V.; Del Amo, G.; Real, M.D.; García-Agustín, P.; González-Bosch, C. Preventive and post-infection control of Botrytis cinerea in tomato plants by hexanoic acid. Plant Pathol. 2008, 57, 1038-1046. [CrossRef]

45. Varsha, K.K.; Devendra, L.; Shilpa, G.; Priya, S.; Pandey, A.; Nampoothiri, K.M. 2,4-Di-tert-butyl phenol as the antifungal, antioxidant bioactive purified from a newly isolated Lactococcus sp. Int. J. Food Microbiol. 2015, 211, 44-50. [CrossRef] [PubMed]

46. Dharni, S.; Gupta, S.; Maurya, A.; Samad, A.; Srivastava, S.K.; Sharma, A.; Patra, D.D. Purification, Characterization and In vitro Activity of 2,4-di-tert-butylphenol from Pseudomonas monteilii PsF84: Conformational and Molecular Docking Studies. J. Agric. Food Chem. 2014, 62, 6138-6146. [CrossRef]

47. Raza, W.; Ling, N.; Yang, L.; Huang, Q.; Shen, Q. Response of tomato wilt pathogen Ralstonia solanacearum to the volatile organic compounds produced by a biocontrol strain Bacillus amyloliquefaciens SQR-9. Sci. Rep. 2016, 6, 24856. [CrossRef] [PubMed]

48. Dhingra, O.D.; Sinclair, J.B. Basic Plant Pathology Methods, 2nd ed.; CRC Press: Boca Raton, FL, USA, 1995; ISBN 0-87371-638-8.

49. Garrity, G.M. Bergey's Manual of Systematic Bacteriology; Springer: New York, NY, USA, 2005; Volume 2, pp. 883-904.

50. Choma, I.M.; Grzelak, E.M. Bioautography detection in thin-layer chromatography. J. Chromatogr. A 2011, 1218, 2684-2691. [CrossRef] 